\title{
機械捺染
}

\section{Roller Print}

青 木 美保子

\section{はじめに}

昭和初期にあって、庶民が普段着として身につけていた 着尺地の染色の多くには、機械捺染の技法が用いられ、庶 民の衣生活は大いに華やいだものとなった。

機械捺染の技法は、明治後期に西洋から京都に移植され た銅製凹型円筒捺染機つまりローラー捺染機によるものが 日本に扔ける䠢矢である。その後、印刷式捺染機やスクリー ン型捺染機も開発されるが、ローラー捺染機が日本にはじ めて導入された機械捺染機であることに加え、昭和前期あ たりまで普及率が最も高く、そのために我が国では当時、 機械捺染といえばローラー捺染を意味するほどであった。 庶民には高嶺の花であった文様が、この量産性の高い染色 技法の普及によって身近なものとなり、一般女性の多くが 気軽におしゃれを楽しむことができるようになったのであ る。

ローラー捺染は、大量生産を目指す繊維産業の近代化の 流れのなかで脚光を浴びたわけであるが、一方で、大量生 産であるがゆえの安価な製品イメージにより、低い評価し か与えられてこなかった傾向がある。そして、近代纎維産 業の調查研究の対象としても、これまで見過ごされてきた。 そのうえ、需要が急速に落ち込んだ現在にあって、この技 法は過去のものとして、次第に忘れ去られてゅく可能性も でてきた。しかし、流行や人びとの好みに柔軟に対応し、 時代のデザイン傾向の形成に多大なる貢献をしたという点 において、ローラー捺染は、産業史あるいは染織史や服飾 史研究、さらには風俗史研究の分野で、取り上げるにふさ わしい研究対象であるように思える。

本稿はこのような視座から、京都の繊維産業の変遷のな かに機械捺染の位置づけを試み、改めてこの染色技法の意 義を問い直そうとするものである。ただし、本稿で取り上 げる機械捺染は、前述のような理由から、ローラー捺染を 意味するものとする。

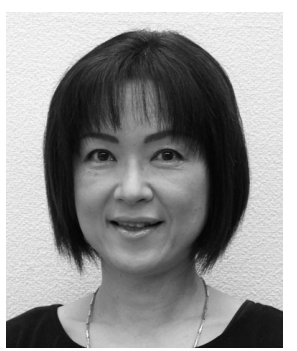

MIHOKO AOKI

神戸ファッション造形大学 准教授 京都工芸纎維大学文化遺産教育研究セン 夕ー 特任准教授 博士 (学術)

T673-0001 兵庫県明石市明南町 2 丁目 1-50

Tel: 078-927-0771 Fax:078-927-0774

E-mail:mihoaoki@saturn.sannet.ne.jp

〈専門〉服飾史、ファッションデザイン
なお、この機械捺染に関する調査研究は、京都工芸繊維 大学文化遺産教育研究センターの活動の一環として行った ものであり、同センターの企画で、平成 $22(2010)$ 年 8 月 9 日から 10 月 1 日まで、京都工芸繊維大学美術工芸資料館 で、展覧会「ここにもあった匠の技－機械捺染－」を開催 した(図 1)。本稿は、その内容を基に、検討・考察を加え たものである。

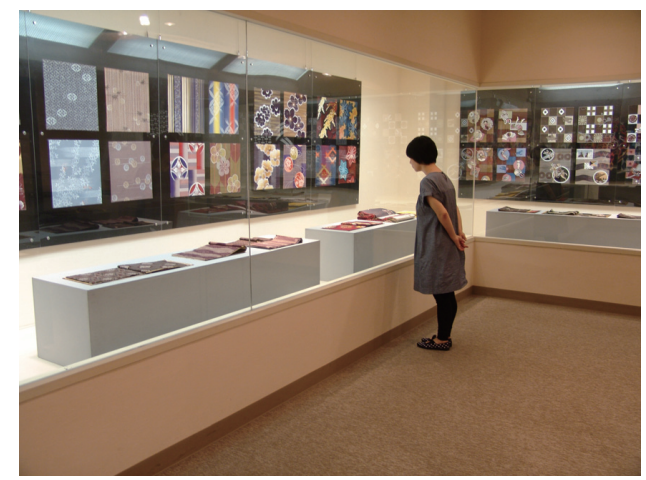

図 1 展覧会「ここにもあった匠の技－機械捺染－」会場 風景

\section{1. 日本におけるローラー捺染の歴史}

京都の染織産業には、応仁の乱の後発展した西陣織、江 戸時代中期に宮崎友禅の名を冠して始まった友禅染などの 伝統産業があり、都の地京都は絹織物の中心産地として確 固たる地位を築いてきた。都の東遷も京都にとっては発奮 材料となった。明治初期、西陣は西洋からジャカードやバッ タンなどの技術を導入することで近代化を図り、全国の織 物業の近代化を斢引した。一方、明治後期に初めて京都に 輸入されたローラー捺染機は、その後、多くのこの業界関 係者の努力で、国産機も製作されるなどしてこの機械捺染 の技法は全国に普及し、染色業の近代化の足掛かりをつ くった。

ローラー捺染機を我が国で初めて輸入し使用したのは、 モスリンの写し染の技術を広瀬治助(写し友禅の考案者)に 伝授した堀川新三郎で、英国より6 色片面機 1 台を購入し 堀川工場を創業したのは、明治 31 (1898) 年のことであっ た。そして時を前後して、西陣に明治 28(1895) 年創業の 五二会綿ネル株式会社もまたフランス製 2 色両面機 1 台を 輸入し、機械捺染に着手する。同社は、その後明治 42(1909) 年に大規模の工場を新築し日本製布株式会社と改名し、捺 染機 13 台を設置して一大工場となった。また明治 32 
(1899)年、堀川新三郎と共同事業主の立場にあった大阪の 千州安兵衛が、堀川工場を離れ、元同工場の捺染技師吉川 喜作を同伴して渡英し、6 色片面機 1 台を購入、明治 33 (1900) 年には吉川喜作が独立し、2 色両面機にて綿ネルの 捺染を開始し、同年、紀州綿布精工株式会社が 4 色両面機 を輸入した。その後、京都、大阪、和歌山、名古屋など各 地の染色会社がローラー捺染機を輸入し、大正 8、9(1919 1920)年頃に機械捺染の工場は急増した。

我が国で機械捺染業者の嗃矢となった堀川工場や五二会 綿ネル株式会社は、おもにモスリンと綿ネルを対象として いたが、機械捺染を綿の着尺地に施すことを考え起業した 人物もいた。都染捺染合名会社を起こした安村長兵衛と佐 貫太兵衛である。同社は英国から特注の小幅 2 色兩面機 1 台を輸入し、明治 $35(1902)$ 年より中形や絣、縞物など着 尺綿布の機械捺染を行った。

その後、彫刻技術の発達に加え、京都が染色業の分業体 制の整っている土地柄であることや、小幅機械の設備が大 幅に比べ軽少であることも手伝って、明治末期から大正初 期にかけて小幅機械捺染の工場は多数興ってきた1)。

このような小幅のローラー捺染機の普及は、絣のように 糸の段階で染め分けた後に織ることで表現する文様や、絞 りのようにひとつひとつ手作業で布を括り表現する文様な ど、途方もない時間をかけて製作されていたものが、機械 捺染で模倣的に表現されることで、一般大衆がそれまで高 価で入手し辛かった着尺模様を安価で手に入れることを可 能にした。ここに、西洋の捺染綿ネルに追いつき、さらに は海外への輸出を目指した機械捺染とは異なる目的と発展 の様子を見出すことができるのである。

\section{2. 着尺図案と図案家寺田哲朗について}

明治 27、8(1894、1895) 年頃、図案家という職業が社会 的に認められるようになり、着物図案にはめざましい展開 が見られた。しかし、図案家の多くは、本画の延長線上に ある帯や友禅の図案を手がけ、天地のない着尺図案を描く ことはなかったため、着尺図案に限っては、従来の小紋や 縞など旧態依然の状況であった。そこで、図案家高坂三之 助は、着尺の図案家を技芸員とした「京都図案協会」を明 治 41 (1908) 年に創立、彼の功績によって着尺図案は大き く発展し、華やかな着尺地が普及することとなった。

機械捺染の着尺地需要が急増した明治 42、43(1909、 1910)年頃、それまでの図案を用いず伝統的な着尺模様を やりくりする生産方法ではその需要に対応することができ なくなった染織業者は、「京都図案協会」の活動の甲斐も あってか、着尺図案の重要性を認識することとなった。大 正初期には全国的に機械捺染会社の設立が相次ぎ、捺染着 尺地、なかでも捺染絣が大量に生産されるようになった。 そして昭和初期、着尺の図案家は、花形職業のひとつとなっ た。

京都工芸繊維大学では、まさにその時期に大活躍してい た図案家のひとりで、後に日本図案協会の副理事長もつと
めた寺田哲朗の図案と寺田が収集保管していた生地見本を 大量に所蔵している。

明治 41(1908) 年に愛媛県で生まれた寺田哲朗(本名 寺 田哲夫) は大正 12 年小学校卒業後上洛し、布施喆詮の塾に 入門する。布施喆詮は、明治 40(1907) 年京都美術工芸学 校卒業後大阪のモスリン問屋の意匠部員を経て着尺図案家 として活躍し、大正末期には機械捺染の絣を得意とする図 案家として名を馳せた人物である。以来、寺田は布施のも とで図案を学び、昭和 4 年の独立後は多くの門下生を養成 しつつ、機械捺染の図案家として活躍した。

この寺田の図案を、以下、(1)図案にみる匠、(2)図案にみ る世相、(3)図案にみるモダン、この3つの視点で考察して みたい。

\section{(1) 図案にみる匠}

絣や絞りなど伝統的染織技法によって表現される意匠が 描かれた図案は、本物の生地と見紛うほど忠実に表現され ている。織糸のように整然と引かれた細い線、手括りで防 染して染め出したように見える文様、一瞥するだけではと ても紙に手で描いた図案には見えない(図 2)。驚嘆に值す る技術である。

図案構成は、ロールの円周にあわせモチーフが、図案の 上下でつながるように配置されている。図案のなかには、 ちょうど中央で切れているものがある。これは、描いてい く過程で、端に近い部分を描く際、すでに描いた中央部分 を切り、上下を繋げたうえで描いたものである。

図案は彫刻の業者に渡ると、複数枚に分けてトレースさ れ、ロールに彫刻されて、そのロールが染色工場に渡り、 繰り返し染色されることになる。このような巧緻な罒案が あってこそ、手工芸による染織技法を模倣した機械捺染の 着尺地が生まれるのである。

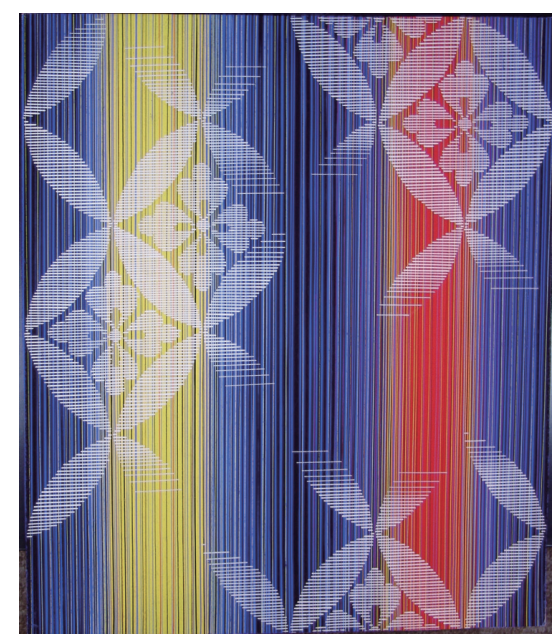

図 2 図案(京都工芸繊維大学蔵)

\section{(2) 図案にみる世相}

機械捺染が庶民の日常着の染色方法として主流であった ことから、この捺染による消費性の強い着尺地には、時代 の嗜好が反映された図案が多く見られる。 
昭和 $10(1935)$ 年、日本政府は神武天皇の即位から 2600 年に当たるとされた昭和 15(1940) 年に向けて「紀元二千 六百年祝典準備委員会」を発足させ記念行事を計画した。 そのイベントの一つが、東京オリンピックであった。日本 は、昭和 11(1936) 年 7 月、初のオリンピック招致に成功 する。しかし、昭和 13(1938) 年 7 月、一触即発の国際情 勢のなか、閣議で開催権の返上が正式に決定し、オリンピッ クは幻に終わった。オリンピックの開催を記念した図案は、 この昭和 11(1936) 年から昭和 13(1938) 年の間に制作され たものと推測できよう。

また、このようなきな臭い世情を反映した図案も数多く みられる。浴衣用とみられる図案には、飛行機文様(図 3) や戦意高揚を表現した文字文様、男子着物用の図案には、 兵隊、鉄砲、ヘルメットなど戦争に纒わる文様が描かれて いる。

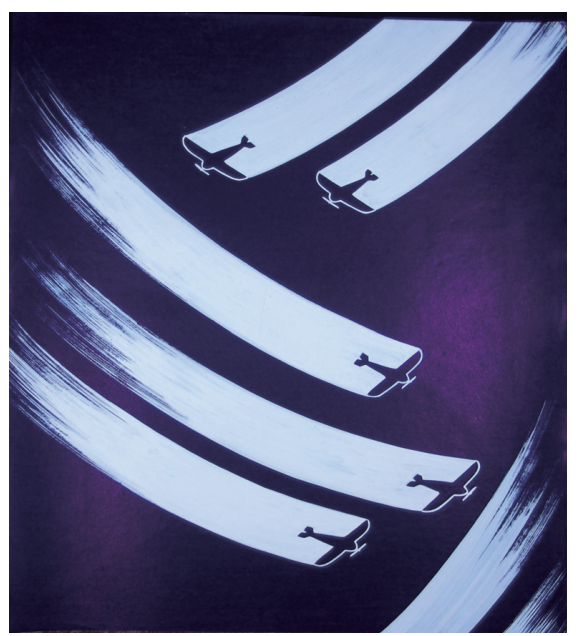

図 3 図案(京都工芸繊維大学蔵)

\section{(3) 図案にみるモダン}

機械捺染の和服は、普段着であるが故の冒険心も手伝っ てか、大胆な文様と色使いのものが多い。伝統文様を中心 に展開する現代の和服には見られない潔さが感じられ、そ のユニークさには心引かれるものがある(図 4)。

ここで改めて語ることもないかもしれないが、庶民が ファッションを楽しむ時代となった昭和初期、女性の多く は和服を身につけていたわけで、シーズンごとに発表され る新柄に心奪われる女性も多かったはずである。そして、 当時その流行を牽引していたのは、有名遣服店をその前身 とする百貨店であった。百貨店の多くは社内に意匠部を持 ち、年 2 回の展示会に向けて、染織業者と消費者に新柄傾 向の情報を発信していた。つまり百貨店がトレンドセッ ターの役目を担っていたのである。次々に新柄を創り出す 必要があった百貨店は、学者や画家などの有識者を巻き込 んで、社会の動向や最新の芸術傾向を分析し、和風、洋風、 とりまぜて、時代の美意識を和服の柄に展開した。当時、 和服の新柄は社会の関心事だったのである2)。

研究熱心な寺田は、新しい図案のアイデアを求めて、し ばしば百貨店高島屋に足を運んでいたという。図案家に
とっては、トレンド調査も大衆の心をつかむ図案の制作に は欠かせない仕事であった。高島屋の百選会は, 昭和初期 には「ウルトラモダンでシーズンごとに思い切って派手な ものや、突拍子もないものを発表し……」と雑誌で評され たこともあるほど、流行に敏感な女性たちにとっては注目 される展示会であった。そのような高島屋の着物図案は、 さぞかし寺田の創作意欲をかきたてたことであろう。

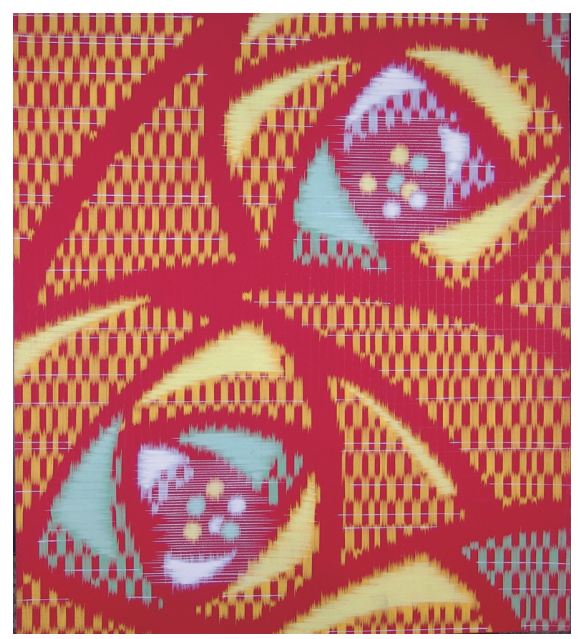

図 4 図案(京都工芸繊維大学蔵)

\section{3. 生地見本}

寺田の収集した資料には、大量の捺染着尺地を中心とし た生地見本が含まれている。本来、新しい図案考案の参考 にと保存されていたものなのかもしれないが、今や貴重な 歴史資料である。

多くの見本帖の表紙には「○○絣」、「○○銘仙」「「○ 絞り」など、伝統的な染織技法名を含む商標名が書かれて いるのであるが、それらをよく観察すれば機械捺染の生地 見本である。庶民にとっては、手軽におしゃれ心を満足さ せるありがたい商品だったに違いない。しかし、「手軽」 とか「気軽」といった表現はふさわしくないほどに、布に 染められた繊細で巧緻な文様からは、高度な彫刻技術や染 色技術を読み取ることができるのである(図 5)。

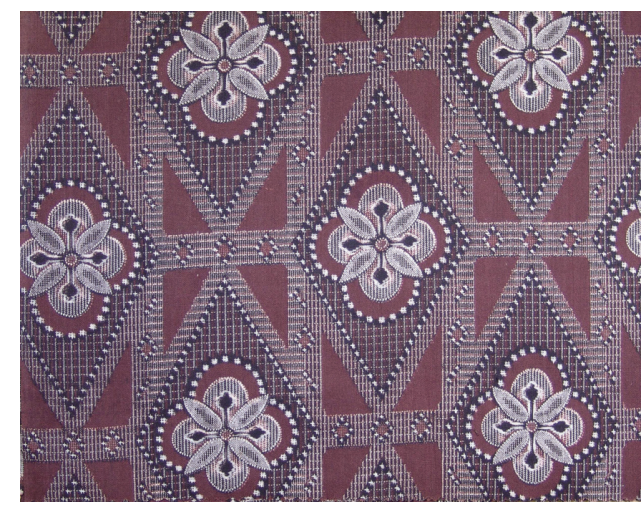

図 5 機械捺染の生地見本(京都工芸繊維大学蔵)

\section{4. 機械捺染の技術}

ローラー捺染は、戝案から色ごとにロールの版をつくる 彫刻と、その版をセットした機械で捺染する染色の工程の 
大きく二つに分けることができる。この二つの工程におけ る技術について考察するために、ローラー彫刻に関しては、 京美彫刻株式会社、染色に関しては太田重染工株式会社に ご協力いただいた。工程と技術の詳細をここに記すことは 省略するが、以下、それぞれの工程において職人の技とい う視点で筆者が特に注目した点に限って報告する。

彫刻工程における職人の技(協力 : 京美彫刻株式会社) 京美彫刻株式会社は、先代社長住田明が、大正 8(1919) 年、徳岡彫刻所に入所し、捺染彫刻士として活躍後、昭和 34(1959)年に独立して興した会社である。徳岡彫刻は洋風 の広幅彫刻を、京美彫刻は和風の小幅彫刻の受注を請け負 うという棲み分けが条件の創業であった。昭和初期の彫刻 技術は手彫りが中心であった。現在では写真転写をして エッチングする技法が中心となっているが、技術は日々進 化し、フィルムレスの新技術も普及しつつある。

今回は、現在の作業方法に加え、当時の技術での作業も 再現していただいた。

\section{・トレース}

現在はパソコンを使用しているが、それ以前はすべて手 作業で、墨を用いトレースしていたそうである。鮫小紋の 丸い点は爪楊枝を用い(図 6)、先のカットする位置を変え ることによって大きさを変えて表現し、細い線は金泥書と いう極細の筆で描いた。

現在のパソコンでのトレースでは、以前のような手描き の味を充分に表現することは難しいが手間暇を考えるとや むを得ないことのようだ。

作業は、発注者の依頼により図案家が描いた図案をもと に色別の版ごとに変化を付けながら写し取っていく。例え ば平坦にみえるモチーフをはっきりと浮き立ってみえるよ うにと依頼があれば、モチーフのアウトラインを描いた下 絵を作り、また別の下絵では濃淡のぼかしを強調する。

図案を染色に適した表現に、あるいはさらに趣のある表 現にする能力が要求される作業であり、図案家が描く図案 が商品の意匠の良し悪しを左右することは当然のことであ るが、このトレース作業が、意匠の質をさらに高めるので ある。

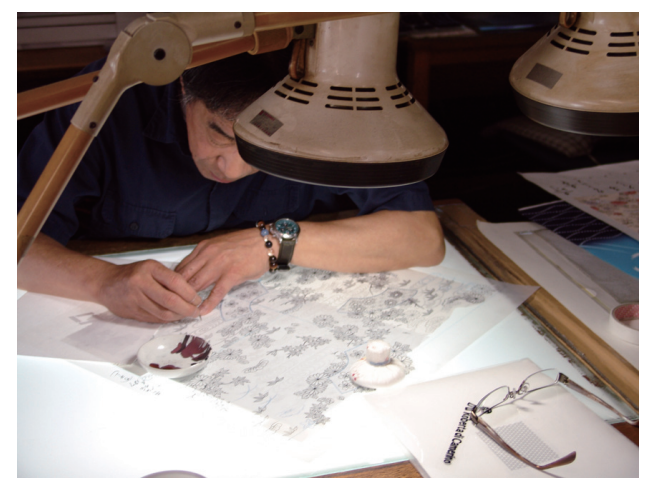

図 6 手描きのトレース

\section{- 手彫り}

トレースした下絵は銅ロールに転写されエッチングされ るのであるが、この技術が普及するまでは、銅ロールに転 写された図はすべて手で直接彫られていた(図 7)。グレー バーやピンという道具を使って、力を加減しながら表現さ れる線やぼかしには、手彫り独特の味があったという。

近年までエッチング後に味付けとして若干の手彫りの作 業が加えられていたが、この技をもつ職人は高齢化し、道 具をつくる会社もすでに無い。今回の調査では、無理にお 願いして手彫り作業を実演していただき、その様子を動画 として記録した。おそらくこの動画が数年後には消え去っ た技術の記録として貴重な資料となることであろう。

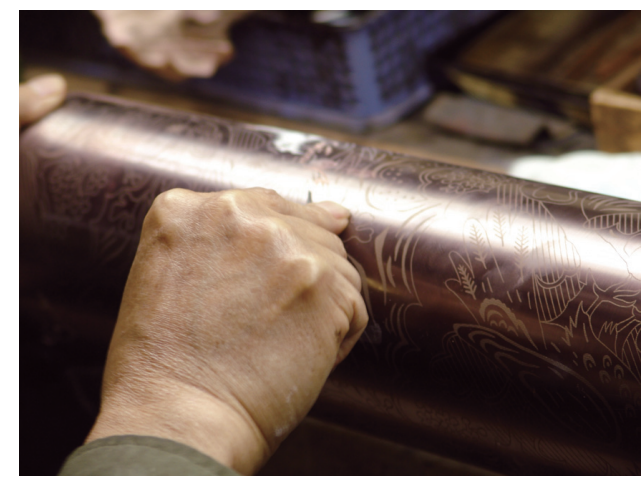

図 7 銅ロールの手彫り

・エッチング

エッチングの工程においても職人の勘が頼りの作業が あった。腐食にかける時間は、気温によって変化するため、 その調節も長年経験に拠るという。

染色工程における職人の技(協力：太田重染工株式会社) 太田重染工は、先代社長太田重太郎が大正 11(1922)年 に小嶋弥七の染色工場に修行に入り、昭和 30(1955)年に 独立して創業した広幅ローラー捺染の会社である。因みに 小嶋弥七はモスリンの写し染の技法を開発した堀川新三郎 の染工場の従業員であったが、明治 29(1896)年に独立し て起業した人物である。太田重染工でローラー捺染を手が けるようになったのは昭和 50 (1975) 年頃からである(図 8)。

\section{・染料の調合}

捺染糊を作る作業では、染料調合の際、その割合は勘に

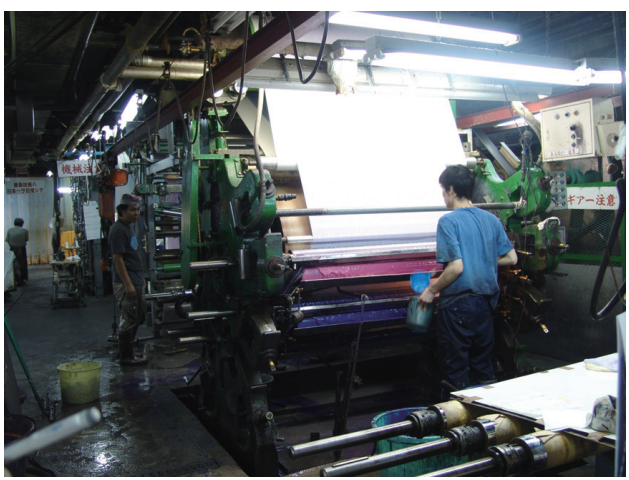

図 8 太田重染工株式会社の現在の捺染機と作業風景 
頼るところが大きい。依頼主の会社の好みの色傾向を知り つくした長年の経験も調整に生かされるそうである。

・ロールの版合わせ

各ロールの版を重ね合わせる技術は、機械の進化によっ て容易にはなったようだが、それでも、シノという道具を 使用して行われる素早い微調整は、経験を積んだ職人の技 である。

\section{・ドクターの研ぎ}

ロールに圧着し彫刻部分以外の糊すべてを取り除く役目 をするドクターは、鋭利な刃物のように研ぐ必要がある。 地味ではあるが欠かすことができない重要な作業であり、 高度な技術を必要とする。

\section{5. 木製凸版ローラー捺染機}

日本に銅製凹版のローラー捺染機の技術が移植される以 前に、和歌山で手廻しの木製凸版のローラー捺染機が作ら

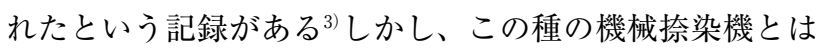
別の木製凸版ローラー捺染機を京都市産業技術研究所繊維 技術センターでは 1 台所蔵している(図 9)。この珍しい捺 染機は株式会社染匠おぐらから寄贈されたものであるが、 この機械が活躍した経緯からも世相を読みとることができ る。

太平洋戦争の戦時体制は、平和産業抑制を目的に多くの 機械捺染工場に統合を迫った。この統制によって、小倉健 染工場、山本伊友禅工場、松井秀捺染工場、宮部染工場、 その他現在のところ名前が判明していない工場も含め、計 5〜6社の工場が統合され、山本伊太郎を社長、松井秀三 を専務として、機械捺染機 1 台で細々と営業することと なった。もちろん、使用されなくなった機械捺染機は金属 供出で軍に回収された。

戦後もこの状態が続き業務が激減したままの状態であっ た小倉健染工場の主人小倉健吉は、手の空いた時間に、知 人である早瀬染工場の主人から譲りうけたこの木製凸型の 円筒捺染機で染着尺を製造した。

この捺染機考案者の早瀬に関する情報は、明石厚明著『日 本機械捺染史』記載の明治 31 (1898) 年から昭和 15(1940) 年までに起業した捺染業者の情報を記した京都捺染工場 録() に以下のように記されている。

「早瀬染工場／早瀬淳一郎／大正十年頃特殊ブロック捺 染の考案をなし捺染機を入れて研究に従事十二年捺染装置 の特許を得又立体模様の研究特許出願中である、現在は冬 眠中」

銅製ロールの機械捺染機は高価なもの、小さな染工場に とっては容易に購入できるものではなかったに違いない。 染工場の主人早瀬は自力で縦横高各 $1 \mathrm{~m}$ 程度の 1 色染めの 簡易な捺染機の開発を思いついた。早瀬はすいぶんと手の 器用な人物であったという ${ }^{5)}$ 。

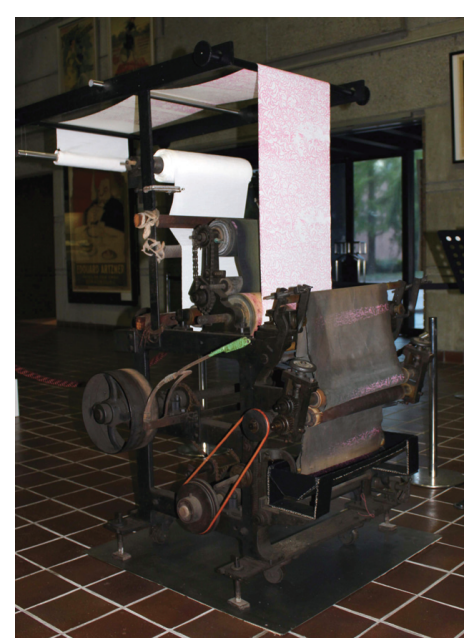

図 9 木製凸版ローラー捺染機(京都市産業技術研究所繊 維技術センター蔵)

\section{6. 機械捺染隆盛の時代}

戦後の混乱が治まると、モンぺ姿から解放された庶民た ちの和服需要は急増し、捺染業界は生産に追われた。その 需要にあわせ、先陣を切って機械捺染機を導入した染色工 場のひとつ亀田富染工場で、当時の様子を伺うことができ た(図 10)。

大正 8(1919) 年、京友禅の染屋として先々代社長亀田富 太郎が創業した亀田富染工場は、昭和 20 年代後半に大量 生産に対応するために機械捺染機を導入した。その後多く の染色業者が機械捺染機を設置し、大量の反物が市場に供 給された。当時、庶民は新しい反物を買い求める一方で、 たんすに眠っていた和服をほどき黒染めにして、その上か ら新たな模様付けをする方法で新柄を楽しんだ。亀田富染 工場では、黒染めの生地には機械捺染機で糊をつけ、乾か ないうちに金粉をまく方法で模様をつけていたそうである。 亀田富染工場社長亀田和明氏は、「子供の頃、工場は黒く 染めた布ばかりといった感じでした」と語る。因みに、こ の黒染めに関しては他の染工場でも証言を得ることができ た。無地染め専門業者の中井染工場は、戦後、ほどいた和 服を黒く染める仕事でずいぶん忙しかったという。

\section{おわりに}

以上、昭和初期に隆盛を極めた機械捺染について、その 歴史に触れるとともに、作業工程ごとにその技術を検証し

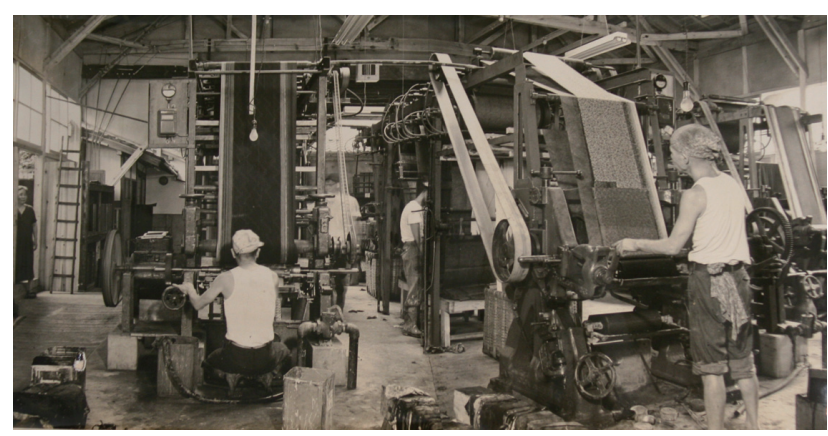

図10 昭和 30 年頃の亀田富染工場の機械捺染の様子 (原写 真：株式会社亀田富染工場蔵) 
考察を行った。

この染色技法の普及によって多くの女性が華やかな日常 着を身につけることができるようになった。庶民の衣生活 を豊かにしたという点においてその功績は大きく、服飾史 の視点から興味深い。

図案からは、その巧緻な表現に高度な技術を確認すると ともに、時代の美意識や世相を読み取ることができた。

木製凸版ローラー捺染機からは、それに縓わって当時の 捺染業界の状況に関する知見を得ることができ、加えて、 染工場の職人が自ら考案したという点において職人の情熱 を、さらには、戦争という不遇な時代にあっても、したた かに生きた職人の機知やエネルギーを感じとることができ た。

彫刻と染色の工程においては、各所に職人が経験によっ て身につけた技術を確認することができ、機械捺染が、機 械を介しているとはいえ手仕事に支えられた染色技術であ ることがわかった。

機械捺染の調査・研究を通して、改めて気づいたことは、 伝統産業として注目されることの多い友禅染や西陣織など の手工芸に関わる匠だけが、京都の地場産業としての繊維 産業を支え、育ててきたのではないということである。永 い歴史をもつ京都の繊維産業においては、時代が必要とし
注目されそして消え去った技術も多く、新旧入れ替わりな がら続いている染織技術の側面を見逃してはならないと思 う。過去のものとなった技術のなかには詳細が不明なもの もある。将来は未知ではあるがもはや時代の花形にはなり えない機械捺染の詳細を記録しておくことの価值はあるよ うに思える。

\section{参考文献}

1）機械捺染の沿革に関しては、明石厚明、『日本機械捺 染史』(日本捺染史刊行會、1943 年)を主な資料とした。

2）大正・昭和初期の百貨店の着物図案に関しては、青木 美保子、「大正・昭和初期の服飾における流行の創出 一高島屋百選会を中心にー」(『デザイン理論』No.44、 2004 年、 pp.1 17)、青木美保子、「大正・昭和初期 の着物図案 - 松坂屋の標準図案を巡って -」(『風俗史 学』No.34、2007 年、pp.34 59) 参照

3）明石厚明、『日本機械捺染史』、日本捺染史刊行會、1943 年、 pp.131-135

4) 同上、pp.61-97

5）この早瀬に関する情報、および小倉健吉氏がこの捺染 機を使用するに至った経緯は、氏が語った回想談とし て、氏の御子息から伺った。 